\title{
Redefining Human Security for Vulnerable Migrants in East Asia
}

\author{
Jiyoung Song
}

School of Social Sciences, Singapore Management University, 90 Stamford Road, Singapore 178903.

E-Mail: jysong@smu.edu.sg

Submitted: 5 August 2015 | In revised form: 23 November 2015 | Accepted: 24 November 2015 |

Published: 14 December 2015

\begin{abstract}
This article proposes human security as an analytical framework to understand the current trends of irregular migration (both forced and unauthorised) in East Asia and revisits the seven pillars of human security defined in the 1994 Human Development Report by the United Nations Development Programme (UNDP). It explains how the concepts of human security are parallel to those prescribed in international human rights conventions but different in terms of the attitude towards states. Human security does not directly challenge state authority and adds a sense of urgency and moral authority that requires extra-legal measures by the states. The author argues that human security is the securitisation of human rights and is a better framework and policy discourse than human rights to engage with state and non-state actors, especially in East Asia where political leaders are more receptive to the former idea. The study draws examples from stateless Rohingyas, undocumented sex workers in Thailand and Singapore, trafficked brides from Vietnam and Cambodia, and smuggled North Korean refugees in China to demonstrate the nexus between human security and irregular migration.
\end{abstract}

Keywords: asylum; East Asia; human security; smuggling; trafficking; undocumented migrants

\section{Introduction}

In spite of the increasing roles played by individuals and non-state actors, states still hold the primary responsibilities to protect and guarantee human security of citizens and residents within their territorial borders. The State is not just an actor that enacts and amends legislation on transnational migration between states and implements policy measures, but is also a structure under which domestic and international, private and public actors, interact with one another. Transnational migration is one such area where states are the gate-keepers of their own territorial boundaries and provide rules and regulations about immigration. Cross-border migration can be approached from different perspectives. While state sovereignty, territorial integrity, national security or criminal justice perspectives represent a conservative voice [1-7], liberal and crit- ical scholars focus more on individual freedom of movement, the global economic structure and migrants' socioeconomic conditions [8-10].

This article offers a critical review of different schools of thoughts on migration and security from conservative, liberal and critical perspectives, which is followed by a critical assessment of the Copenhagen School's securitisation theory. The main purpose of the review is to examine how academic discourses of international security have evolved over the years, especially after the end of the Cold War, from state- and defence-centric to more people-centred perspectives, merged with other discourses of human rights and sustainable development. After an overview of key debates on human security, it examines the 1994 UNDP definition of the seven pillars of human security as the most comprehensive and encompassing framework. It conceptually dismantles the seven 
pillars - namely personal, community, political, economic, food health and environmental securities-and shows how similar the contents of human rights and human security are. It concludes that human security is the securitisation of human rights that attaches a sense of urgency and paramount importance to affected people, regardless of their legal status, and that requires extra-legal and extrapolitical measures by the concerned states.

The study draws on a number of recent examples from East Asia (both South and North) where migrants risk their lives to cross the borders through unauthorised land or sea routes in order to relocate themselves and their families to more secure places. They include North Korean 'smuggled refugees' [11], undocumented Cambodian workers and trafficked fishermen in Thailand [12], overstayed Bangladeshi workers in Japan [13], stateless Rohingyas [14], trafficked Vietnamese brides in Korea [15] and Karen refugees in Thailand [16], to name a few. Migrant' decisions to move across their national boundaries are driven by their natural instinct for survival to go to a more secure place even when the movement is unauthorised by relevant state authorities. Irregular migration is a highly complex area of studies as most cases present mixed migration with multiple causes in a vicious circle. In other words, a migrant who wanted to escape from poverty and discrimination, pays for a smuggler to cross the border and ends up being a victim of human trafficking. Where $\mathrm{s} /$ he is rescued, s/he realises s/he could have claimed refugee status, so s/he does. Still, s/he has no right to work. Within the broad category of unauthorised movement, the boundaries and key definitions of irregular migration (which includes undocumented labour migration, human trafficking, people smuggling and asylum seeking) are all blurred and the process of irregular migration is highly unpredictable.

While migrants are in such dire conditions, the current human rights framework is insufficient to solve the problem. According to Article 13(2) of the 1948 Universal Declaration of Human Rights, individuals have the right to leave a country of origin. However, international human rights law does not provide an express right for the individual to reside elsewhere nor place a duty upon other states to receive them. Mobility is therefore incompletely defined and protected under the existing human rights regime. It is the states that decide whom they want to receive as residents, temporary and permanent alike, and accept as citizens. State obligations to protect and respect basic human rights of those who are not their citizens have not been properly observed under international law. In this regard, human security may offer a powerful language and discourse for international and regional cooperation to tackle irregular migration. The term promotes the urgency and paramount importance attached to affected people regardless of their legal status, as well as to hosting societies. Human security highlights the on-going challenge posed by irregular migration that requires immediate measures by the concerned states that go beyond traditionally defined domestic rules and regulations on immigration or charitable humanitarian consideration. By redefining the seven pillars of human security in the context of irregular migration in East Asia, the study contributes to the clarity of mixed terminologies and multiple causes of irregular migration as well as to the growing body of knowledge and theoretical development for the existing literature on the nexus between human insecurity and irregular migration.

\section{The Securitisation of Migration}

This section critically reviews three main theories of migration in relation to security. The real world of scholars and practitioners present a mixture of some of these basic ideas and the lines among the three schools are highly blurred (see Table 1 below). Nevertheless, the purpose here is to provide the most distinctive lines of argument on this area. Philippe Bourdeau [1] aptly introduces three models of securitisation of migration. The first and mainstream model is from the realist tradition of International Relations (IR). Robert Kaplan [17] warned that Western states should fear the 'coming anarchy' associated with mass migration while Samuel Huntington [18] declared that the persistent flow of Hispanic immigrants would constitute a major potential threat to America's cultural and political identity. One of the most well-known conservative migration scholars is Myron Weiner [19] who stated that 'advanced industrial countries can protect their borders from invading armies but not from hordes of individuals who slip into harbours, crawl under barbed-wire fences and wade across rivers'. Weiner's migration-security nexus [20] draws what he calls the Security Stability Framework on how international migration creates conflict within and between countries from a realist perspective, which sees migration as a potential threat to national security. For realists, therefore, the expansion of international migration is dangerous for state sovereignty and the balance of power among states in the international system and would create violent conflicts among states [21].

For liberals, on the other hand, national borders should be open for free trade, labour mobility and individual liberty, although there are several different sub-groups within the liberal camp. For example, neoliberals would advocate for free trade, fewer regulations and unrestricted labour mobility while classical liberals focus on individual liberty, human rights and justice. Liberal scholars envisage the "client politics model' [22-24] or the 'embedded liberalism model' $[25,26]$, both of which support freedom of movements. In this liberal perspective, international institutions and international laws are supposed to set rules and regulations that respect individual freedom and democracy, and that contribute to shaping more cooperative and open-minded state behaviour towards globalisation and international migration. Free(r) movements, however, on the contrary, have made many migrant workers' conditions worse instead of helping them alleviate poverty, underdevelopment and corruption, an issue which the next group of scholars 
Table 1. Three models of securitisation of migration.

\begin{tabular}{|c|c|c|c|}
\hline & Realism & Liberalism & Critical Theory \\
\hline \multirow[t]{2}{*}{ Basic premisses } & $\begin{array}{l}\text { Migration creates conflict within and } \\
\text { between countries. Migration is a po- } \\
\text { tential threat to national security. }\end{array}$ & $\begin{array}{l}\text { National borders should be open for } \\
\text { free markets, labour mobility and indi- } \\
\text { vidual liberty. }\end{array}$ & $\begin{array}{l}\text { Insecurity and fear are mostly imag- } \\
\text { ined and constructed by mundane, bu- } \\
\text { reaucratic practices and decisions of } \\
\text { everyday politics. }\end{array}$ \\
\hline & $\begin{array}{l}\text { International migration affects state } \\
\text { sovereignty, the balance of power } \\
\text { among states, and the nature of vio- } \\
\text { lent conflicts in the international sys- } \\
\text { tem. }\end{array}$ & $\begin{array}{l}\text { The threats realists argue are posed } \\
\text { by migrants can be negated by the } \\
\text { rules and regulations set up by inter- } \\
\text { national institutions and international } \\
\text { law. }\end{array}$ & $\begin{array}{l}\text { Security professionals, conservative } \\
\text { media, nationalist politicians and } \\
\text { xenophobic individuals foster the } \\
\text { creation of fear mongering around } \\
\text { migration. }\end{array}$ \\
\hline \multirow[t]{3}{*}{ Scholars } & Robert Kaplan & Gary P. Freeman & Didier Bigo \\
\hline & Samuel Huntington & Virginie Guiraudon & Ole Wæver \\
\hline & Myron Weiner & Christian Joppke & \\
\hline
\end{tabular}

address.

Critical theorists oppose both realist and liberal views, arguing that security is neither about survival nor about urgency and exceptional practices. Rather, security is the 'result of mundane bureaucratic decisions of everyday politics that create a sense of insecurity, fear, danger and unease' $[27,28]$. Didier Bigo identifies this as the 'governmentality of unease'. According to him, the securitisation process is above all 'routinised practices of professionals of security, essentially police and bureaucrats'. This relates to Ole Wæver's securitisation theory to identify existential threats from imagined enemies and to highlight 'speech act'. The speech acts are not only done by bureaucrats or security professionals but also by the conservative media, nationalist politicians or xenophobic individuals who post their opinions on the Internet and they spread over a few minutes across space. The state (or Bigo's security professionals), in this sense, waits until normative equilibrium is reached in the society and belatedly reacts to social demands in democratic society. Threats may not exist, but fear does endogenously within individuals living in the system of mass migration. It is not just created by external sources of bureaucrats.

The Copenhagen School, which is part of the critical theory and is led by Wæver, gives specific methodological insights into the securitisation of irregular migration. Barry Buzan's Securitisation Theory (ST) $[29,30]$ provides a framework to theorise how East Asian states are securitising irregular migration and to identify which security norms the states are constituting and utilising over the years. As Bourdeau [1] says, ST is 'the most widely applied and fully developed model of relationships between migration and security' and a 'most creative and productive analytical framework'. Securitisation is, by definition, the 'process of integrating migration discursively and institutionally into security frameworks that emphasise policing and defence' [1]. Like social constructivism [31], one of the greatest strengths of ST is that it shifts the focus of analysis away from merely material factors to socio-cultural and normative ones.

Wæver [32] himself identifies his own ST as an analysis of 'actual linguistic practices to see what regulates discourse'. The Copenhagen School examines what practitioners 'do in talking security'. Wæver's notion of security is that it is the 'result of a move that takes politics beyond the established rules of the game and frames the issue as above normal politics', which also applies to human security. However, his interpretation of the designation of existential threat is negative in a sense that it is only to justify the use of extraordinary measures or special powers such as enforcement and secrecy. His view of security is a 'failure to deal with issues as normal politics'. For Wæver, therefore, de-securitisation is the optimal long-range solution, which limits the scope for interpretations of security to human dimensions.

I would add a new human dimension to Waever's ST. There have been changing conceptions of security from state-centric to people-centred. I would still place this new dimension under the post-structural critical school as my version of human security framework is going beyond both realist/liberal rational theory and instead focusing on nonlinear circular processes of human insecurity and irregular migration. Previous work on the securitisation of migration focus on the negative notion of security as urgency, control and power [23,33]. Maggie Ibrahim [34] for example, calls the securitisation of migration the 'latest and most modern form of racism'. In fact, fear-mongering, criminal imagery of migrants, witch-hunting or 'othering' particular ethnic groups are old tactics of securitisation of migrants. However, this limited and negative state-centric perspective of securitisation does not capture the changed concepts of security in a more humane way and that includes considerations of the agency of migrants. The Rohingya boat people crisis in May 2015 also presents multi-faceted human security issues of irregular migration concerning the poverty, conflict and discrimination that drive migrants into the illegal sea routes that are operated by traffickers. 
There is another problem with ST that is the disconnection between theory and empirical evidence. As Bigo $[28,35]$, the founding father of the Paris School, points out, actual policy practices often reveal patterns different from those found in official discourses. Many have tried to fill this gap. Bourdeau [1] brings his own cases from Canada and France whereas Melissa G. Curley and Wong Siu-lun [36] provide Northeast Asian case studies. Feminist security studies offer valuable observations and analyses on how different forms of migration are securitised or undersecuritised [37-41], which provided inspiration for the current study. Migrants' self-organising behaviour and interactions among themselves and with the state migration regimes are key to understanding the evolutionary correlation between migration and security.

\section{Human Security: Securitisation of Human Rights}

As explained above, the conventional notion of security focuses on national defence, military security or territorial integrity of sovereign states, virtually synonymous with 'defence' $[42,43]$. Notions of personal, cultural or environmental security emerged and the reconceptualisation of security has been carried out by IR theorists [30,42,44,44-51]. The major breakthrough was the 1994 UNDP report. In the report, the UNDP laid out two broad categories of human security: 'freedom from fear' and 'freedom from want' [52-54]. It argued that 'human security is not a concern with weapons - it is a concern with human life and dignity', best insured through prevention and people-centeredness. It detailed seven components of human security: personal, community, political, economic, food, energy and environment securities that are interdependent with one another.

Since then, human security has been revisited for further investigation for its utility and its relation to other global political concerns [43,55-57]. Some have a narrow definition of human security as 'vulnerability to physical violence during conflict' [58] while others share a broader concept, linking it with other areas such as development or globalisation $[59,60]$, which is often represented as the Canadian vs. Japanese conceptions of human security [61]. Ernst Haas [62] long argued that the security literature needs to learn from the 'evolutionary epistemology' of global life. Similarly, Mark Duffield [63] agrees that human security provides a means of distinguishing geopolitics, the security of states, from biopolitics, the security of population. For many in East Asia, economic, food, energy and environmental issues are real and immediate threats to their peoples' survival and resilience. Developing countries like Myanmar, Vietnam, Cambodia, the Philippines and Indonesia send many economic and marriage migrants overseas and migrants send remittance back to their countries of origin. North Korea has chronic food shortage [64-66]. China, Japan and South Korea started planning to secure long-term food security, especially rice, and energy secu- rity, which both involve seasonal labour forces. Japan, Indonesia and the Philippines are vulnerable to natural disasters such as typhoons, whereas the Greater Mekong region faces man-made environmental degradation through mining and dam construction, activities that result in forced eviction at times.

Each state's historical (post-colonial), political and cultural backgrounds constitute its attitude to human rights vs. human security. Many in East Asia were under Western colonial rule (except for Korea which was under the Japanese rule) and have authoritarian political structures, which have been deeply embedded in hierarchical maledominant role-based cultures or religions. Governments are under pressure for their lack of transparency and accountability, rising middle-classes or ethnic rivalry. In this environment, the political elites are more receptive toward the idea of collective (human) security while being resistant to individual human rights. A state as an actor also wants to survive as individual migrants do. The former prime ministers of Singapore and Malaysia, Lee Kuan Yew and Mahathir bin Mohamad, for example, defined human rights as Western concepts that were not suitable for many Asian countries. The former Singaporean foreign minister Kishore Mahbubani also argues that human rights are an 'aggressive alien Western concept' [67]. The default assumption in human rights is that the state is the potential perpetrator either by committing human rights violations or by omitting its obligations to protect human rights. Statesociety relations are confrontational under the doctrine of human rights. In the language of human security, however, states remain the primary guarantors of human security or providers of goods and services for people's well-being while being able to establish normal authority in international society by looking after its own people as well as vulnerable migrants. Having a closer examination of the contents of the seven pillars of human security endorsed by the UNDP in 1994 [52], however, I would argue that they are all within the realm of international human rights as seen below Table 2 .

Whereas human rights challenge state authority and sovereignty and often accuse states of being potential perpetrators, human security expects state moral authority, expands state responsibilities to non-citizens, i.e. vulnerable migrants regardless of their legal status, and urges trans-political supra-national measures that go beyond existing national mechanisms. It is the urgency and the magnitude of impact on vulnerable irregular migrants that transcends state sovereignty and territorial integrity and that can affect hosting societies on a greater scale if no proper measures are taken in time. This requires immediate transnational cooperation. In this regard, a good state may want to seize the opportunity to take ownership of human security and play a responsible role for the regional security. 
Table 2. Human Security and Human Rights.

\begin{tabular}{|c|c|c|}
\hline $\begin{array}{l}\text { Seven Pillars of } \\
\text { Human Security }\end{array}$ & International Human Rights & $\begin{array}{l}\text { Provisions of Human Rights } \\
\text { Treaties }\end{array}$ \\
\hline Personal Security & $\begin{array}{l}\text { The right to life, liberty and security; not to be discriminated, based on race, ethnicity, } \\
\text { language, religion, sex, political opinion or social origin, birth, disability, gender, sexual } \\
\text { orientation; to freedom from violence, torture, slavery, exploitation, arbitrary arrest, or } \\
\text { summary execution; to recognition before the law, fair trial, privacy, family, property, } \\
\text { identity/nationality, movement and residence, gender equality, freedom of thought and } \\
\text { education. }\end{array}$ & $\begin{array}{l}\text { UDHR Articles 1-19, 26; IC- } \\
\text { CPR Articles 2-3, 6-20, 23- } \\
\text { 4, 26; ICESCR Articles 2-3, } \\
\text { 10, 13-4; CEDAW; CRC; CAT; } \\
\text { and other ILO conventions no } \\
\text { forced labour or child labour }\end{array}$ \\
\hline $\begin{array}{l}\text { Community Secu- } \\
\text { rity }\end{array}$ & $\begin{array}{l}\text { The right to cultural life; to preserve cultural practices, values or heritage from sec- } \\
\text { tarian violence or not to be discriminated against, based on certain race, ethnicity, } \\
\text { nationality or religion. }\end{array}$ & $\begin{array}{l}\text { UDHR Article 27; ICCPR Ar- } \\
\text { ticle 27; ICESCR Article 15; } \\
\text { CERD; and MWC }\end{array}$ \\
\hline Political Security & $\begin{array}{l}\text { The rights to freedom of assembly, political participation; not to be discriminated } \\
\text { based on political opinion, to vote and to stand for election, to free and fair elec- } \\
\text { tion, to freedom of speech, to form and maintain political organisations, or to organise } \\
\text { social movements. }\end{array}$ & $\begin{array}{l}\text { UDHR Articles 2, 20-21; IC- } \\
\text { CPR Articles 21-22, } 25\end{array}$ \\
\hline Economic Security & The rights to basic income, social security, work and rest, trade union. & $\begin{array}{l}\text { UDHR Article 22-4; ICE- } \\
\text { SCR Articles } 6-9 \text {; and other } \\
\text { ILO conventions on minimum } \\
\text { wage, etc.) }\end{array}$ \\
\hline Food Security & The rights to adaquate standard of living, freedom from hunger, access to basic food. & ICESCR Articles 11 \\
\hline Heath Security & $\begin{array}{l}\text { The rights to standard of living, health, to be protected from infectious or chronic } \\
\text { diseases and to access health services. }\end{array}$ & $\begin{array}{l}\text { UDHR Article 25; ICESCR Ar- } \\
\text { ticles } 12\end{array}$ \\
\hline $\begin{array}{l}\text { Environmental Se- } \\
\text { curity }\end{array}$ & $\begin{array}{l}\text { The rights to adaquate standard of living, clothing, housing, and clean environment, } \\
\text { especially water and air, or the right to be protected from man-made environmental } \\
\text { disasters. }\end{array}$ & ICESCR Articles 11 \\
\hline
\end{tabular}

Unlike the misconceived idea of human rights as an imperial Western concept among many authoritarian leaders in East Asia, human security has the potential to grow more as a foreign policy concept. There are signs many East Asian elites are already receptive to the idea of human security. Amitav Acharya [68] went even further, arguing that human security is originally an 'Asian' concept as Mahbub ul Haq, who is the main author of detailing the concepts of human security in the 1994 UNDP report, is an 'Asian' scholar. Japan has initiated the Asian approach to human security by embracing socio-economic aspects such as food and energy security in contrast to the Canadian emphasis on the 'freedom from fear' in armed conflict. The Japanese government saw human security comprehensively covering 'all the menaces that threaten human survival, daily life and dignity-for example, environment degradation, violations of human rights, transnational organised crime, illicit drugs, refugees, poverty, anti-personal landmines and other infectious diseases such as AIDS' $[43,69]$. Japan's comprehensive security, therefore, bears both a traditional statist notion of closer military cooperation with the US and non-traditional economic, energy and food security [70]. Although Acharya [68] remains pessimistic in arguing that ASEAN countries' main concern is regime survival and legitimation as in the case of Singapore's 'Total Defence' [71] rather than genuine concern for people's well-being and security, the two are inseparable.

Furthermore, some East Asian leaders embrace and mobilise human security in their public speeches [72-74] (on the Asian conception of human security, see: $[75,76]$ ). In 2002, Chinese Premier Zhu Rongji and ASEAN lead- ers jointly declared on cooperation in the field of nontraditional security at the sixth China-ASEAN Summit in Phnom Penh, Cambodia. At the Symposium on 'Realizing Human Security in Asia' in Tokyo in 2010, the SecretaryGeneral of the Association of Southeast Asian Nations and former Thai Foreign Minister, Surin Pitsuwan, endorsed the concept of human security as 'a rather comprehensive concept... [that]... will not be in competition with the issue of state sovereignty. In fact, it is making the state's sovereignty more meaningful because state security and state sovereignty, also would involve responsibility' [77]. Pitsuwan also connected the concept to social safety nets in the wake of the 1997 Asian Financial Crisis. In the recent publication of the Armed Forces of the Philippines [78] Internal Peace and Security Plan: Bayanihan, the wholeof-nation 'human security' approaches were identified as the strategic planning for peace and security, natural disasters and other illicit activities such as human trafficking, piracy and people smuggling.

\section{4. 'Human' Securitisation of Irregular Migration}

The final section of the article examines the nexus between human (in)security and irregular migration. Many have tried to bring in broader concepts of human security in migration studies, rather than traditional national and border security perspectives. Elspeth Guild and Joanne van Selm [79] reconceptualise security as 'political and legal security', 'cultural and identity security' and 'personal and economic security' in their study on the impact of immigrants on hosting countries. Literature 
on the migration-development nexus $[80,81]$, migrationdevelopment-security [82], and migration-globalisationhuman security [83] employs people-centred security concepts. The nexus between human insecurity and irregular migration has been observed in the East Asian context. Dewi F. Anwar [84] has tried to weave together the ideas of human rights, security and irregular migration. In particular, she identified new threats to human security as the exploitation of irregular workers, the growing incidence of people smuggling and human trafficking. However, Anwar did not concretise the contents of human security and used the term with 'non-traditional' security interchangeably, which made the concept very vague. With further embodiment and comparison with established international human rights norms, the UNDP's human security lens can provide an alternative agent-based analysis for the motivations of migrants, the vulnerability they face as well as the potential or imagined threats they pose to hosting societies.

Human (in)security has been the main driver for irregular migration. Because of their irregular status, migrants' human security comes under greater threat (no matter where they end up), which feeds into the vicious cycle of insecurity-triggered migratory patterns. Unless this vicious circle is broken by urgent extra-legal measures by the concerned states, both vulnerable migrants and hosting societies can end up in highly insecure situations. In spite of the greater risk that irregular migration poses for all societies, the term 'irregular migration' has been associated with the illegality of people's movements. It is labelled clandestine, illegal, sans papier (undocumented), uncontrolled, unlawful, unauthorised, alien without residence status, or non-compliant. In 1974, the United Nations made the first reference to irregular migration in connection with the treatment of 'illegal aliens' [85]. In the following year, the UN General Assembly adopted Resolution 3449 (30) where it called on the UN system to use the term 'nondocumented' or 'irregular' in official documents rather than 'illegal' migrants. The International Organization for Migration defines irregular migration as the 'movement that takes place outside the regulatory norms of the sending, transit and receiving countries'. I would define irregular migration as emerging patterns of people's mobility that does not conform to established rules, norms, customs or morality, which include unauthorised illegal migration as well as forced migration. Following Martin Ruhs and Bridget Anderson's compliance approach [86], 'unauthorised' here has two meanings: one is movement that has not abided by existing migration regulations in a given state and the other is that states do not have laws (yet) to regulate illicit migration. For this article, people 'affected' [87] by irregular migration fall into four categories: 1) unregistered, overstayed or misusing-visa labour migrants; 2) asylum seekers, stateless people, or IDPs; 3) trafficked persons or 4) smuggled people. In reality, however, these four categories are blurred and cross-boundary: undocumented Cambodian fishermen become easy targets for traffickers [88] and
North Korean asylum seekers in China get 'help' from missionary smugglers to use the underground railway to cross the border to Southeast Asia [89].

East Asia produces a large number of irregular migrants inter-regionally but also intra-regionally. Border controls are not rigidly enforced in certain places due to geographical challenges or the lack of government capacity. East Asia's diverse and vibrant environments create intraregional migration for labour, sex, marriage or freedom. East Asia has high degrees of demographic, political, economic, socio-cultural and ethnic diversity, which makes the cross-border movements more frequent and fluid as in diffusion and osmosis in physics. In China, it has the world's biggest population of 1.38 billion and one of the smallest, Brunei with only 412,000 in 2012 [90]. In terms of income, East Asia has the lowest GDP per capita of Lao PDR (US\$ 751 ) and the highest of Japan (US\$ 37,433) in 2013 [91]. In the Golden Triangle, the Balkans of Asia, there are numerous ethnic minorities sharing the national borders between Thailand, Myanmar and Lao for trade or employment. The International Organisation for Migration (IOM) [92] recognises that irregular migration remains one of the biggest challenges across the region 'with the most common forms being unauthorised labour migration movement and trafficking for labour and sexual exploitation, sometimes through international marriages'. The following subsections will introduce a few exemplary cases of irregular migration in relation to human (in)security, based on the author's own reading, observation and fieldwork in the region for the past decade. The list is not exhaustive.

\section{Asylum Seeking}

In forced migration, personal, community, political and environmental insecurities (physical safety, ethnic and political violence as well as natural disasters and man-made environmental damages) push migrants to neighbouring countries. Many ethnic minorities such as the Karen, Mon or Rohingya peoples escape from state-induced discrimination and armed conflict in Burma to neighbouring countries such as Thailand and Malaysia through whatever possible land and sea routes, despite the fact they are unauthorised channels (fieldwork in Ban Dong Yang and Mae La camps in Thailand and focus group interviews with 58 refugees in total between 2013 and 2015). Some pay for smugglers to get them out of situations of violence and poverty. Others are deceived by human traffickers and kept in confinement until ransom is paid or until they are sold for sex or labour exploitation. North Koreans also escape from state-induced political violence, food and economic insecurity, and severe floods and draught in the 1990s. They head to China and then down to Thailand, Vietnam or Cambodia, knowing that the border crossing is illegal both in sending and receiving countries (fieldwork in Yanbien, China in 1999, Seoul, South Korea in 2000-2005 and Bangkok, Thailand in 2012).

International human rights or refugee laws have been 
ineffective in responding to imminent threats to asylum seekers and hosting populations as the states concerned do not fully respect human rights norms and instead prioritise sovereignty and national security. Burma, North Korea, China, Vietnam and Cambodia have the worst records of state compliance with international human rights and they are not bound by humanitarian or refugee conventions either. Under international law, none of the concerned countries show commitment to the respect for, or protection of, human rights for those vulnerable asylum seekers. These states merely treat these vulnerable individuals as illegal migrants who violate domestic immigration regulations. This does not deter asylum seekers from leaving their countries of origin (because it does not address the original issue of insecurity that pushes irregular migration), but it does encourage underground smuggling networks to grow, which places the migrants in greater danger.

Because of the precarious and illegal status of asylum seekers and the lack of sufficient government measures, migrants' food, health, environment and community securities are at stake in hosting countries (lack of access to basic food, exposure to unhygienic environments and communicable diseases, discrimination against certain ethnic groups or threats from locals to report to the authorities). For Karen refugees, Thailand offered temporary shelter for more than a decade where refugees received food, health services, basic education and vocational training. In the case of North Korean asylum seekers, China has turned a blind eye and they remain in the hands of underground Christian missionaries or smugglers. The existence of asylum seekers and refugees often creates diplomatic tension between sending and receiving countries. Burma and Thailand have regular dialogues how to handle the Karen refugees. Vietnam once sent 486 North Koreans in a chartered Korean Air flight to South Korea and North Korea publicly condemned the decision. While Thailand allows some Karen refugees to remain as residents, China repatriates North Koreans and tightens border control, based on the bilateral agreement with North Korea. The latter case opens underground smuggling and trafficking networks that can penetrate borders, which only make both migrants and citizens more vulnerable and place regional security in greater danger. As China closes the borders with North Korea, the region's economy slows down and community cohesion is disturbed [93]. Trafficking in persons and people smuggling occur in commercial land and sea routes [94]. Turbulent and poorly managed borders can also attract other related criminal activities such as goods smuggling and fraud [95] that have impact on not just asylum seekers but the hosting populations.

\section{Undocumented Labour Migration}

The next group is undocumented labour migrants who seek better economic security and knowingly violate immigration rules and work permit requirements. These are mostly unskilled workers and they make up the largest number of migrant workers in Asia [96]. There are no fixed sending or receiving countries. A decision to move to another country to find work is relative and non-linear. Decisions are made through interactions with migrants' neighbours, families and friends. Employment agencies play a significant role and some have exploitative practices that are not regulated by states. While existing flows from countries like Bangladesh, Indonesia and the Philippines are constant, migrant workers from Vietnam, Cambodia, Laos and Burma have also entered the global labour market. Among economic migrants who come with proper visas, many become irregular as they overstay or misuse visas. Up to one in four migrant workers in Asia may have illegal status [97]. According to the International Labour Organisation [97], labour flows from Indonesia and Thailand to Malaysia are largely illegal and Thailand hosts up to 1.7 million illegal workers. Undocumented migrants have no access to justice and are not entitled to legal protection from abuse, the non-payment of salaries. Bangladeshi or Nepalese factory workers in Japan overstay and become illegal migrants [98]. Cambodian seasonal workers cross the border to Thailand without proper travel documents or work permits [99]. Philippine sex workers enter Singapore with social visit passes and solicit in streets or bars (fieldwork in Singapore in 2012 and in-depth interviews with eight sex workers). They are targets of police raids and arrested for the breach of immigration rules.

States treat them as illegal migrants who breach the national laws on immigration and work permits. Furthermore, the growth of irregular migration in East Asia is linked to both governments' unwillingness to effectively manage migration and to employers' desire for cheap labour [100]. Most Asian countries have tended to turn a blind eye to undocumented workers at times of economic growth and to campaigns of mass expulsion in economic downturns. These workers have no recourse or access to justice when their rights are violated. Hosting countries do not recognise their legal rights as the latter has no legal standing in the country of their residence. International human rights laws do little to protect irregular migrant workers. Most countries that host undocumented migrant workers have not signed or ratified the International Convention on the Protection of the Rights of All Migrant Workers and Members of Their Families [101].

In the meantime, the very presence of undocumented labour migrants in a country, when not properly managed, poses potential threats to personal, community, economic, food, health and environmental securities for hosting societies. The public is exposed to health hazards from unmanaged epidemic or transmittable diseases through human contact because irregular migrants share the same space as host societies. Undocumented migrants are not covered by national healthcare systems. Accumulated grievances may trigger communal violence against the local population. Leaving undocumented migrant workers unprotected can create long-term socio-economic problems for hosting societies. Many governments, however, 
tend to focus on their illegal status and the deportation of these workers once caught no matter how long they have contributed to the hosting country's economy. Repatriation may provide the concerned government a short-term cost-effective solution. However, in the long run, exploitation and unfair treatment can bring about unintended diplomatic and political conflict between the sending and receiving countries.

\section{Trafficking in Persons and People Smuggling}

The third and fourth categories of irregular migrants are people who are affected by human trafficking and people smuggling. They include victims, survivors, their families, brokers, aid workers and anyone who migrate or have migrated to transport other people for the purposes of exploitation or for pure financial gain. These two terms are often confused. The former involves a form of exploitation in the final destination and can happen within a national boundary whereas the latter refers to the movement of people from one country to another through an unauthorised channel. In the case of trafficking, individual traffickers can be charged for their criminal activity. States can also be held responsible for failing to protect the human rights of trafficked persons. Smuggling, however, is defined as a transnational organised crime and no state is legally responsible for the protection of smuggled people unless they prove themselves exploited by smugglers or seek political refuge. Vulnerable populations who live in zones of conflict and poverty become targets of traffickers for exploitation. Young people are particularly vulnerable. North Korean women and women from refugee camps in Thailand are sold and resold to Chinese men as wives for sexual exploitation and domestic servitude [94]. Young Vietnamese and Cambodian women are arranged to marry South Korean, Japanese and Taiwanese men through international match-making agencies who work for profit [15]. Many of them are confined at home with their passports confiscated by their husbands. Uneducated and poor women and children from Burma and Indonesia work as domestic workers in Singapore, often not paid for several months or years because of the money they owe the employment agencies. They are also verbally and physically abused by their employers and denied their day-off from work [102]. Their movements are managed by profitoriented employment or marriage agencies.

While not denying irregular migration has to be solved in part through the prosecution of organised criminals and protection of victims, it is also a serious human problem that needs to be seen from the agent's perspective rather than treating them merely as criminals/victims and putting them in prisons/shelters. Poverty, lack of education and social stigma are identified as causes of trafficking in persons $[103,104]$. There are also other facilitating factors such as a symbiotic relationship between established (legalised) and underground (criminalised) sectors [105]. Without assistance from local security guards, police and other law enforcement officials, irregular migration would be impossible. Trafficked or smuggled migrants, because of their precarious legal status, are exposed to the great risk of exploitation, fear of deportation, physical and mental abuses and other human rights violations and discrimination.

Human rights are not likely to be a dominant foreign policy norm in the region. While only the Philippines and Indonesia are signatories to the International Convention of the Protection of Migrant Workers and Their Families, many East Asian countries have ratified the Convention against Transnational Organised Crime and its protocols on human trafficking and people smuggling [106]. A rare occasion states act together is the recent migrant smuggling incidents at sea [107]. It was security not human rights that made states respond to the crisis. International news cover the stories of stranded migrants at sea from Burma, Bangladesh and Sri Lanka which include all four irregular migrant groups I have described earlier in this paper. For example, they include Rohingya asylum seekers, many of whom are victims of human trafficking, and smuggled Bangladeshi migrants, who were to be undocumented migrant workers. The only two Muslim-majority countries, Malaysia and Indonesia, offered temporary shelters while the Thai, Singaporean and Australian governments turned them away [108]. International humanitarian or human rights laws do little to change state behaviour when they collide with notions of state sovereignty and territorial integrity. The urgency human security attaches to stress the magnitude of impact on human lives has a better chance to induce state action.

\section{Conclusion}

Irregular migration is a transnational human security problem that requires urgent extra-legal measures and goes beyond normal politics. International human rights norms have not been so effective as to induce state action to protect vulnerable migrants as well as hosting societies. For this reason, this article went in search for a more appropriate discourse that could capture the nature and impact of irregular migration on people. It found the 1994 UNDP's seven pillars of human security most comprehensive and also parallel to the norms of international human rights with changing state responsibilities. The multifaceted 1994 UNDP framework moves away from the narrow vs. broad concepts of human security and helps better understand the causes and consequences as well as the constitutive processes of irregular migration. Human security does not challenge state sovereignty as much as the language of human rights appears to, but gives states greater ownership over the causes and consequences of human insecurity and the opportunity to exercise moral authority in international relations. It therefore has a better chance to induce state action than the existing human rights regime, especially in the East Asian context. This comprehensive human security approach to irregular migration stands a better chance than the narrow criminal justice or individu- 
alistic human rights perspectives.

This article identifies the lack of personal, economic, food and environmental securities as the main drivers for irregular migration. Migrants move across their national borders to find a safer place for their survival, very often knowing that the way to do so is not authorised by the relevant migration regimes. They may reside in foreign countries without proper permits or with misused documents. The act of irregular migration, which is often forced by states or prompted by other profit-minded individuals or corrupt government officials, puts migrants under a new set of human insecurities not just for migrants themselves but also for hosting populations. Human insecurity caused by irregular migration is not a matter of migrants vs. citizens but a matter for all migrants and citizens. Human security provides a better normative framework to understand the motivations and human costs of irregular migration. Each trajectory of irregular migration has its own path dependency, learning curves, interactions with other stakeholders such as families, brokers, smugglers, employers or immigration officers, and feedback loops. Irregular migration is a complex system where a large number of heterogeneous agents are interacting with one another in a highly unpredictable manner.

The current study introduces a number of case studies from East Asia. However, the implications described above can be universal. While being careful about providing concrete policy recommendations, I would argue restrictive immigration rules and political measures do not solve the problem. In fact, they drive migration underground and deepen human insecurity for vulnerable migrants and their hosts. Open borders do not automatically solve the problem, either. Open borders are highly unlikely, especially in Northeast Asia where North Korea is testing its nuclear and missile programmes. Even in Southeast Asia, the idea of open borders for a common market can only be realised in the distant future because of the income gap between the most and least developed countries in the region. Open borders without access to justice and

\section{References and Notes}

[1] Bourdeau P. The Securitisation of Migration: A Study of Movement and Order. London, UK: Routledge; 2011.

[2] Newman E, Selm Jv. Refugees and Forced Displacement: International Security, Human Vulnerability and the State. New York, NY, USA: United Nations University Press; 2003.

[3] Ong A, Nonini D. In Ungrounded Empires: The Cultural Politics of Modern Chinese Transnationalism. London, UK: Routledge; 1997.

[4] Shain Y, Barth A. International Migration and Sending Countries. Basingstoke, UK: Palgrave; 2003.

[5] Castles S, Miller MJ. The Age of Migration: International Population Movements in the Modern World. information, socially responsible businesses and competent civil society will only drive already vulnerable migrants into increasingly exploitative environments. Providing basic food, healthcare and clean living conditions, regardless of a person's legal status, is not just moral and humanitarian for all irregular migrants but would also be beneficial for better human security of the hosting society, too.

With growing human insecurity not just caused by political violence but more and more by non-political factors such as poverty, underdevelopment, extremism, inequality, social exclusion, and environmental damage, scholars and practitioners in the field need to be able to understand the dynamic and complex nature of irregular migration. The process is not linear but highly unpredictable and constitutive. One such case is the growing number of environmental refugees who are not recognised by the 1951 Refugee Convention or by any international protection regimes. More people are displaced by natural disasters, which immediately place those affected under highly vulnerable food, shelter, health and environmental conditions. These conditions subsequently lead to more serious and detrimental long-term economic deprivation and lack of education. IDPs and refugees then become targets for traffickers. Otherwise, those with resources flee using migrant smugglers and become undocumented labour migrants elsewhere. As I reiterated in this article, the criteria of irregular migration is extremely blurred in real life. The media and policy-makers are better informed by clear terminologies and types of irregular migrants laid out in this article so that when we have a refugee crisis, we do not call it a migrant crisis, or we do not call what is human trafficking migrant smuggling any more.

\section{Acknowledgements}

The current study was funded by the Singapore Ministry of Education (Fund No.: C242/MSS14S004). The author would like to thank the anonymous reviewers for their helpful comments to improve the earlier version of the paper.
[6] Castles S, Davidson A. Citizenship and Migration: Globalization and the Politics of Belonging. London, UK: Routledge; 2000.

[7] Geddes A. The Politics of Migration and Immigration in Europe. London, UK: Sage; 2003.

[8] Brettell CB, Hollifield JF. Migration Theory: Talking Across Disciplines. London, UK: Routledge; 2000.

[9] Joppke C. Selecting by Origin: Ethnic Migration in the Liberal State. Cambridge, MA, USA: Harvard University Press; 2005.

[10] Statham P, Geddes A. Elites and Organized Publics: Who Drives British Immigration Politics and in Which Direction? Western European Politics. 2006;29(2):245-266.

[11] Song J. 'Smuggled Refugees': The Social Construc- 
tion of North Korean Migration. International Migration. 2013;51(4):158-173.

[12] Derks A. Migrant Labour and the Politics of Immobilisation: Cambodian Fishermen in Thailand. Asian Journal of Social Science. 2010;38(6):915-932.

[13] Rahman M, Lian K. The Development of Migrant Entrepreneurship in Japan: Case of Bangladeshis. Journal of International Migration \& Integration. 2011;12(3):253.

[14] Balazo P. Truth \& Rights: Statelessness, Human Rights, and the Rohingya. Undercurrent. 2015;11(1):6-15.

[15] Lee H. Trafficking in women? Or multicultural family? The contextual difference of commodification of intimacy. Gender, Place \& Culture: A Journal Of Feminist Geography. 2014;21(10):1249.

[16] Fuertes A. Birds Inside a Cage: Metaphor For Karen Refugees. Social Alternatives. 2010;29(1):20-24.

[17] Kaplan R. The Coming Anarchy. The Atlantic. 1994;.

[18] Huntington S. The Hispanic Challenge. Foreign Policy. 28 October 2009; Available from: http://foreignpolicy.com/2009/10/28/the-hispanicchallenge/.

[19] Weiner M. The Global Migration Crisis: Challenge to States and to Human Rights. New York, NY, USA: Harper Collins College Publishers; 1995.

[20] Weiner M. Security, Stability and International Migration. International Security. 1992-1993;17(3):91126.

[21] Adamson F. International Migration in a Globalizing World: Assessing Impacts on National Security. In: Kirshner J, editor. Globalization and National Security. New York, NY, USA: Routledge; 2006. p. 35-73.

[22] Freeman GP. Winners and Losers: Politics and the Costs and Benefits of Migration. In: Messina AM, editor. Western European Immigration and Immigration Policy in the New Century. Westport, CT, USA: Praeger; 2002. p. 77-96.

[23] Freeman GP. Immigrant Incorporation in Western Democracies. International Migration Review. 2004;38(3):945-969.

[24] Freeman GP. National Models, Policy Types and the Politics of Immigration in Liberal Democracies. West European Politics. 2006;29(2):227-247.

[25] Guiraudon V, Joppke C. Controlling in New Migration World. London, UK: Routledge; 2001.

[26] Joppke C. Challenge to the Nation-State: Immigration in Western Europe and the United States. New York, NY, USA: Oxford University Press; 1998.

[27] Bigo D. The Emergence of a Consensus: Global Terrorism, Global Insecurity, and Global Security. In: d'Appollonia C, Reich S, editors. Immigration, Integration, and Security. America and Europe in Comparative Perspective. Pittsburgh, PA, USA: University of Pittsburgh Press; 2008. p. 67-94.

[28] Bigo D. Border Regimes, Police Cooperation and Security in an Enlarged European Union. In:
Zielonka J, editor. Europe unbound. Enlarging and Reshaping the Boundaries of the European Union. London, UK: Routledge; 2002. p. 213-239.

[29] Buzan B, Wæver O, Wilde Jd. Security: A New Framework for Analysis. Boulder, CO, USA: Lynne Rienner Publishers; 1998.

[30] Buzan B. Societal Security. In: Wæver O, Buzan $B$, Kelstrup M, Lemaitre P, editors. Identity, Migration and the New Security Agenda in Europe. London, UK: Pinter; 1993. p. 41-58.

[31] Wendt A. Social Theory of International Politics. Cambridge, UK: Cambridge University Press; 1999.

[32] Wæver O. Aberystwyth, Paris, Copenhagen: The Europeanness of New 'Schools' of Security Theory in an American Field. In: Tickner A, Blaney DL, editors. Thinking International Relations Differently. London, UK: Routledge; 2012. p. 48-71.

[33] Beare ME. Illegal Migration: Personal Tragedies, Social Problems, or National Security Threats? Transnational Organized Crime. 1997;3(4):11-41.

[34] Ibrahim M. The Securitization of Migration: A Racial Discourse. International Migration. 2005;43(5):163187.

[35] Bigo D, Tsoukala A. Terror, Insecurity and Liberty: IIliberal Practices of Liberal Regimes After 9/11. London, UK: Routledge; 2008.

[36] Curley MG, Siu-lun W. Security and Migration in Asia: The Dynamics of Securitisation. London. UK: Routledge; 2008.

[37] Hansen L. Gender, Nation, Rape: Bosnia and the Construction of Security. International Feminist Journal of Politics. 2000;3(1):55-75.

[38] Hansen L. The Little Mermaid's Silent Security Dilemma and the Absence of Gender in the Copenhagen School. Millennium. 2000;29(2):285-306.

[39] Enloe C. Bananas, Beaches and Bases. Berkeley, CA, USA: California University Press; 2001.

[40] Ticker A. Gender in International Relations. New York, NY, USA: Colombia University Press; 1992.

[41] Sjoberg L. Gender and International Relations: Feminist Perspectives. London, UK: Routledge; 2010.

[42] Poku N, Graham DT. Redefining Security: Population Movements and National Security. London, UK: Praeger; 1998.

[43] King G, Murray CTJ. Rethinking Human Security. Political Science Quarterly. 2001-2002;116(4):586610.

[44] Baldwin DA. The Concept of Security. Review of International Studies. 1997;(1):5-26.

[45] Matthews JT. Redefining Security. Foreign Affairs. 1989;68(2):162-177.

[46] Thomas C. In Search of Security: The Third World in International Relations. Boulder, CO: Lynne Rienner; 1987.

[47] Wiberg H. (Re-)conceptualizing security. Arms Control. 1992;13(3):487-492. 
[48] Krause K, Williams MC. From Strategy to Security: Foundations of Critical Security Studies. In: Krause K, Williams MC, editors. Critical Security Studies: Concepts and Cases. London, UK: UCL Press; 1997. p. 33-61.

[49] Booth K. Strategy and Emancipation. Review of International Studies. 1991;17(4):313-326.

[50] Jones RW. 'Message in a Bottle'? Theory and Praxis in Critical Security Studies. Contemporary Security Policy. 1995;16(3):299-319.

[51] Wæver O. Securitisation and Desecuritisation. In: Lipschutz RD, editor. On Security. New York: Columbia University Press; 1995. p. 46-86.

[52] Programme UND. New Dimensions of Human Security. New York, NY, USA: Oxford University Press; 1994.

[53] Chen LC. Human Security: Concepts and Approaches. In: Matsumae T, Chen LC, editors. Common Security in Asia: New Concepts of Human Security. Tokyo, Japan: Tokai University Press; 1995. p. 137-146.

[54] Florini AM, Simmons PJ. The New Security Thinking: A Review of the North American Literature. Carnegie Endowment for International Peace; 1998.

[55] Bellamy A, McDonald M. 'The Utility of Human Security': Which Humans? What Security? A Reply to Thomas and Tow. Security Dialogue. 2002;33(3):373-377.

[56] Kerr P, Tow WT, Hanson M. The Utility of Human Security Agenda for Policy Makers. Asia Journal of Political Science. 2003;11(2):89-114.

[57] Evans PM. Cooperative Security and its Discontents in Asia PAcific; The ASEAN Connection. American Asian Review. 2001;19(2):99.

[58] Lodgaard S. Human security: concept and operationalization. In: Expert Seminar on Human Rights and Peace, Palais Wilson, Geneva. vol. 8; 2000. p. $1-21$.

[59] Sen A. Development as Freedom. Oxford, UK: Oxford University Press; 1999.

[60] Sen A. Inequality Reexamined. Cambridge, MA, USA: Harvard University Press; 1992.

[61] Bernard Jr P. Canada and Human Security: From the Axworthy Doctrine to Middle Power Internationalism. American Review Of Canadian Studies. 2006;36(2):233-261.

[62] Haas E. Words Can Hurt You; or Who Said What to Whom about Regimes. In: Krasner S, editor. International Regimes. Ithaca, NY, USA: Cornell University Press; 1983. p. 23-59.

[63] Duffield M. Human Security: Development, Containment and Re-territorialisation. The Globalization of Security. 2005;(2):3-5.

[64] Park KA. Non-traditional security issues in North Korea. Honolulu: University of Hawaii Press, Center for Korean Studies; 2013.

[65] Kim M. Securitization of Human Rights: North Ko- rean Refugees in East Asia. New York, NY, USA: Praeger; 2012.

[66] Lee Sw. Human Security and North Korean 'Food Refugees'. South Asian Refugee Watch. 20012002;3-4:23-40.

[67] Mahbubani K. Can Asians Think? Times Editions; 3rd edition; 2004.

[68] Acharya A. Human Security: East versus West. International Journal. 2001;56(3):442-460.

[69] Ministry of Foreign Affairs of Japan. Diplomatic Bluebook 1999: Japan's Diplomacy with Leadership Toward a New Century. Urban Connections Inc.; 1999.

[70] Satoh Y. The evolution of Japanese security policy: Introduction. The Adelphi Papers. 1982;22(178):1.

[71] According to the Singaporean Ministry of Defence, 'Total Defence' is composed of five pillars: military, civil, economic, social and psychology defence, the last four of which can be translated into political, economic, community and personal securities among the seven human security criteria. Total Defence, however, stresses individual citizen" responsibility to take part in the defence and to play a role for any type of crises rather than the state's responsibility to protect. http://www.mindef.gov.sg/imindef/mindef_websites/ topics/totaldefence/about_us/what_is_td.html\# .VXzVRuuG_Zdlastaccessedon14June2015.

[72] Matsumae T, Chen L. Common Security in Asia: The New Concept of Human Security. Tokyo, Japan: Tokai University Press; 1995.

[73] Tow WT, Thakur R, Hyun IT. Asia's Emerging Regional Order: Reconciling Traditional and Human Security. Tokyo, Japan: United Nations University Press; 2000.

[74] Thiparat P. The Quest for Human Security: The Next Phase of ASEAN? Bangkok: Institute of Security and International Studies; 2001.

[75] Alagappa M. Comprehensive security: interpretations in ASEAN countries. In: et al RAS, editor. Asian Security Issues: Regional and Global. Berkeley, CA, USA: University of California, Institute of East Asian Studies; 1988.

[76] Bajpai K. The Idea of Human Security. International Studies. 2003;40:195-228.

[77] Pitsuwan S. Realizing Human Security in Asia; 2010.

[78] Internal Peace and Security Plan: "Bayanihan". Armed Forces of the Philippines; 2010.

[79] Guild E, van Selm J. International Migration and Security: Opportunities and Challenges. London, UK: Routledge; 2005.

[80] Newland K. Migration as a Factor in Development and Poverty Reduction. Migration Information Source. 1 June 2003; Available from: http://www.migrationpolicy.org/article/migrationfactor-development-and-poverty-reduction.

[81] A special issue at International Migration 2002;40(5) 
covers the migration-development nexus with worldwide case studies. Also see Kathleen Newland, 'Migration as a Factor in Development and Poverty Reduction', Migration Information Source (2003).

[82] Tirtosudarmo R. Migration-Development-Security Nexus: In Search of New Perspectives in the Changing East Asian Contexts. In: Anwar DF, editor. Development, Migration and Security in East Asia: People's Movements and Non-Traditional Security Challenges in a Changing East Asia. Jakarta, Indonesia: The Habibie Center; 2005. p. 13-50.

[83] Graham DT, Poku NK. Migration, Globalisation and Human Security. London, UK: Routledge; 2000.

[84] Anwar DF. Development, Migration, and Security in East Asia : People's Movements and NonTraditional Security Challenges in a Changing East Asia. Jakarta, Indonesia: The Habibie Center; 2005.

[85] The World Population Conference. World Population Plan of Action. Population and Development Review. 1975;p. 163-181.

[86] Ruhs M, Anderson B. Semi-Compliance and Illegality in Migrant Labour Markets: An Analysis of Migrants, Employers and the State in the UK. Population, Space and Place. 2010;16(3):195-211.

[87] Kempadoo K, Sanghera J, Pattanaik B. Trafficking and Prostitution Reconsidered: New Perspectives on Migration, Sex Work and Human Rights. London, UK: Paradigm Publishers; 2005.

[88] Gallagher A, Pearson E. The High Cost of Freedom: A Legal and Policy Analysis of Shelter Detention for Victims of Trafficking. Human Rights Quarterly. 2010;32(1):73.

[89] Choi Jh. North Korean Refugees and the Politics of Evangelical Mission in the Sino-Korean Border Area. The Journal of Korean Religions. 2013;4(2):147173.

[90] United Nations Statistical Division. World Statistics Pocketbook. United Nations Publications; 2013.

[91] GDP per capita (current US\$). The World Bank. Available from: http://data.worldbank.org/indicator/ NY.GDP.PCAP.CD.

[92] Asia and the Pacific, The Context of Migration in the Region. International Organization for Migration (IOM); 2013.

[93] Yonhap. N. Korea-China trade on decline amid icy ties. 11 November 2015. Available from: http: //english.yonhapnews.co.kr/northkorea/2015/11/11/ 99/0401000000AEN20151111002300320F.html.

[94] Lee Wy, Kim Y. North Korean Migrants: A Human Security Perspective. Asian Perspective. 2011;35(1):59-87.

[95] Chestnut S. Illicit Activity and Proliferation: North Korean Smuggling Networks. International Security. 2007;32(1):80-111.

[96] Trends in International Migration. Organisation for Economic Co-operation and Development (OECD);
2003. Available from: www.oecd.org/els/mig/ trendsininternationalmigration2003.htm.

[97] Realizing Decent Work in Asia: Fourteenth Asian Regional Meeting: Report of the Director-General. International Labor Organization; 2006. Available from: http://www.ilo.org/wcmsp5/groups/public/--dgreports/---dcomm/---webdev/documents/ publication/wcms_071313.pdf.

[98] Yoder RS. Deviance and Inequality in Japan: Japanese Youth and Foreign Migrants. Bristol, UK: Policy Press; 2011.

[99] Park M. Over 100,000 Cambodian migrant workers flee Thailand. Cable News Network. 16 June 2014; Available from: http://edition.cnn.com/2014/ 06/16/world/asia/cambodia-thailand-migrants/.

[100] Castles S, Miller MJ. Migration in the Asia-Pacific Region. Migration Information Institute. 10 July 2009; Available from: http://www.migrationpolicy. org/article/migration-asia-pacific-region.

[101] International Convention on the Protection of the Rights of All Migrant Workers and Members of Their Families. Office of the United Nations High Comissioner for Human Rights; 18 December 1990. Available from: http://www2.ohchr.org/english/ bodies/cmw/cmw.htm.

[102] Yea S. Human Trafficking in Asia: Forcing Issues. London, UK: Routledge; 2014.

[103] Lê TQ, nghiên cúru thanh niên (Vietnam) V. Prevention of Trafficking in Women in Vietnam. Labour and Social Affairs Publishing House; 2000.

[104] Boontinand J. Feminist Participatory Action Research in the Mekong Region. In: Kempadoo K, Sanghera J, Pattanaik B, editors. Trafficking and Prostitution Reconsidered: New Perspectives on Migration, Sex Work and Human Rights. Boulder and London: Paradigm Publishers; 2005. p. 175-197.

[105] Beare ME. Introduction. In: Beare ME, editor. Critical Reflections on Transnational Organized Crime, Money Laundering, and Corruption. Toronto, Canada: University of Toronto Press; 2003. p. xixxix.

[106] United Nations Convention against Transnational Organized Crime. United Nations Office on Drugs and Crime; 15 November 2000. Available from: https://www.unodc.org/unodc/treaties/CTOC/.

[107] Bintang R, Hamzah AzA. Hundreds of refugees arrive in Malaysia and Indonesia after Thai crackdown. Reuters. 11 May 2015; Available from: http://www.reuters.com/article/2015/05/11/usindonesia-rohingya-idUSKBNONVOPC20150511\# DU9C20d6CeSDmrXt.97.

[108] Cochrane J. Indonesia and Malaysia Agree to Care for Stranded Migrants. The New York Times. 20 May 2015; Available from: http://www.nytimes.com/2015/ 05/21/world/asia/indonesia-malaysia-rohingyabangladeshi-migrants-agreement.html?_r=0. 